\title{
PENGARUH PROSES CONCHING TERHADAP SIFAT FUNGSIONAL COKELAT (Cacao theobroma cacao L.)
}

\section{The Effect of Conching Process on Functional Properties Of Chocolate (Cacao theobroma cacao L.): A Review}

\author{
Muhammad Rifqi \\ Department of Food Technology and Nutrition, Faculty of Halal Food Science \\ Djuanda University, Bogor West Java, Indonesia \\ rifqimuhammadsuryana@gmail.com
}

\begin{abstract}
ABSTRAK
Cokelat merupakan salah satu produk olahan hasil kakao yang banyak digemari oleh masyarakat. Berdasarkan komposisi bahan penyusunya, terdapat tiga jenis cokelat, yaitu dark chocolate, milk chocolate, dan white chocolate. Proses pembuatan cokelat pada dasarnya meliputi pencampuran bahan, conching, tempering, dan pencetakan. Conching merupakan tahapan penting yang menentukan kualitas mutu dalam proses pembuatan cokelat. Cokelat memiliki kandungan polifenol yang baik bagi kesehatan. Kandungan polifenol pada cokelat memiliki sifat antioksidan yang baik bagi tubuh. Conching merupakan salah satu proses yang paling penting dalam pembuatan cokelat dalam menyatukan adonan, memberikan citarasa yang baik pada cokelat, serta memberikan tekstur yang baik pada cokelat. Proses conching yang digunakan pada proses pembuatan cokelat tidak berpengaruh terhadap menurunnya sifat fungsional pada cokelat dilihat dari aktivitas antioksidanya. Cokelat yang dihasilkan melaui proses conching memiliki aktivitas antioksidan yang termasuk kedalam katagori kuat.
\end{abstract}

Kata kunci: Cokelat, Conching

\begin{abstract}
Chocolate is one of the most popular cocoa products favored. There are three types based on composition of ingredients as follows dark chocolate, milk chocolate, and white chocolate. The chocolate making process in this edition includes mixing ingredients, conching, tempering, then printing. An important stage that determines quality in chocolate making process. Chocolate contains polyphenols which are good for health. The polyphenol content in chocolate has antioxidant properties that are good for healthy. Cocnching is one of the most important processes in chocolate making in joining the dough, giving chocolate a good flavor, and giving chocolate a good texture. The conching process used in the chocolate-making process does not affect the functional decline in chocolate as seen from its antioxidant activity. Chocolate produced through conching process has antioxidant activity which is included in strong category.
\end{abstract}

Keywords : Cacao, Conching

\section{PENDAHULUAN}

Kakao merupakan salah satu komoditas hasil perkebunan yang memiliki potensi yang cukup tinggi di Indonesia (Maulana dan Kartiasih, 2017). Menurut Arif, et al. (2017), salah satu potensi kakao sebagai salah satu komoditas perkebunan di Indonesia adalah berkontribusi dalam peningkatan devisa negara. Berdasarkan data dari Direktorat Jendral Perkebunan tahun 2014, ekspor komoditas kakao memberikan sumbangan devisa terbesar ketiga setelah ekspor komoditas kelapa sawit, dan karet yaitu US $\$ 1,2$ miliar.

Menurut Maulana dan Kartiasih (2017), Prospek pasar kakao di dunia terus mengalami peningkatan dari tahun ke tahun dimana pada tahun 2000-2009 konsumsi produk olahan kakao mencapai $17 \%$. Peningkatan ini terjadi di benua Asia dan benua Afrika dengan peningkatan masing - 
masing sebesar $38 \%$ dan $72 \%$. Menurut (Hasibuan dan Nurmalina 2012), konsumsi kakao per kapita dunia adalah sebesar $0,55 \mathrm{~kg}$ pada tahun 2000/2001, kemudian meningkat menjadi 0,59 $\mathrm{kg}$ per kapita pada tahun 2008/2009. Praseptiangga, et al.,( 2018), berpendapat bahwa tingginya ekspor cokelat ke negara lain berbanding terbalik dengan perkembangan industri cokelat di Indonesia. Tingginya ekspor kakao ke negara tujuan serta umumnya kakao tersebut diolah di negara tujuan menjadi produk olahan kakao, yaitu cokelat hal tersebut menunjukan masih terbatasnya produk olahan kakao menjadi produk sekunder di Indonesia.

Cokelat merupakan salah satu produk olahan hasil kakao yang banyak digemari oleh masyarakat (Arif,et al., 2017). Menurut Praseptiangga, et al., (2018), cokelat merupakan suspense partikel-partikel seperi pasta kakao, susu bubuk, serta gula yang tersusun atas lemak cokelat secara utuh dan terus menerus. Menurut Asriati et al., (2018), berdasarkan komposisi bahan penyusunya terdapat tiga jenis cokelat, yaitu dark chocolate, milk chocolate, dan white chocolate. Perbedaan dari ketiga jenis cokelat tersebut terletak dari penambahan susu pada produk tersebut, dimana dark chocolate merupakan jenis cokelat yang tidak sama sekali menggunakan bahan susu dalam pembuatan produknya sedangkan milk chocolate menambahkan susu pada pembuatan produknya sedangkan white chocolate berbahan baku susu dalam proses pembuatanya. Bahan baku yang digunakan, serta proses yang dilakukan pada pembuatan cokelat akan berpengaruh terhadap kualitas mutu pada cokelat salah satunya adalah dalam aspek fungsional atau kesehatan.

Proses pembuatan cokelat pada dasarnya meliputi pencampuran bahan, conching, tempering, lalu dicetak (Braga et al. 2018). Asriati et al., ( 2018), menyatakan bahwa conching merupakan tahapan penting yang menentukan kualitas mutu dalam proses pembuatan cokelat. Cokelat memiliki kandungan polifenol yang baik bagi kesehatan. Menurut (Moreira et al. 2018), kandungan polifenol pada cokelat memiliki sifat antioksidan yang baik bagi tubuh. Manfaat antioksidan pada cokelat diantaranya dapat menurunkan resiko penyakit jantung dan kanker. Besarnya antioksidan dapat kita lihat melalu aktivitas antioksidan pada cokelat tersebut dalam hal menangkal radikal bebas yang dilakukan dengan pengujian di laboraturium. Menurut Braga et al. (2018), proses conching pada pembuatan cokelat atau produk olahan kakao akan mempengaruhi sifat fungsional yang terdapat pada cokelat. Hal tersebut dikarenakan sifat antioksidan yang terdapat cokelat mudah rusak terhadap suhu tinggi. Ulasan ini membahas proses conching terkait sifat fungsional cokelat dilihat dari aktivitas antioksidannya.

\section{PROSES PEMBUATAN COKELAT (Cacao theobroma cacao L.)}

Cokelat dari hasil pengolahan kakao merupakan salah satu produk yang memiliki manfaat yang baik bagi tubuh karena mengandung senyawa polifenol yang bersifat antioksidan (Moreira et al. 2018). Proses pengolahan biji kakao menjadi cokelat merupakan faktor terpenting dalam menentukan kualitas cokelat. Proses pembuatan cokelat selain berpengaruh terhadap kualitas mutu dari produk tersebut akan berpengaruh juga terhadap sifat fungsional dari cokelat tersebut.

Tahap awal dalam pembuatan cokelat meliputi persiapan bahan baku. Buah kakao yang telah matang secara optimal dibelah untuk mengeluarkan dan memisahkan biji kakao dari kulit buah dan plasentanya. Menurut Ansarullah dan Fardilla (2019), pengupasan buah dilakukan dengan pemukul yang terbuat dari kayu. Proses selanjutnya yang dilakukan adalah biji kakao basah dikelompokkan menjadi empat bagian. Bagian pertama langsung dikeringkan dengan sinar matahari (tanpa fermentasi), bagian kedua dimasukkan ke dalam kotak fermentasi lalu difermentasi selama 1 hari, bagian ketiga difermentasi selama 3 hari, dan bagian keempat difermentasi selama 5 hari. Rosniati dan Suprapti (2009), berpendapat selanjutnya biji kakao yang telah difermentasi dikeringkan hingga kandungan air mencapai $7 \%$.

Proses pembuatan pasta kakao merupakan tahapan dalam merubah nib kakao menjadi pasta kakao yang digunakan sebagai bahan baku dalam pembuatan cokelat. Menurut Maulana dan Kartiasih (2017), pasta kakao merupakan produk yang diperoleh dari biji kakao setelah proses pengolahan yaitu penyangraian dan penggilingan (Talbot 2009). Pasta kakao dibuat dari biji kakao kering melalui beberapa tahapan proses sehingga biji kakao yang semula padat menjadi bentuk cair atau semi cair. Pasta kakao dapat diproses lebih lanjut menjadi lemak dan bubuk cokelat yang 
merupakan bahan baku pembuatan produk makanan dan minuman (Ruku, 2008). Pasta kakao atau yang biasanya disebut cocoa mass atau cocoa liquor adalah hasil pengolahan biji kakao kering yang antara nib dan kulitnya menggunakan mesin desheller atau pemecah biji kakao, kemudian nibs dihaluskan hingga terbentuk pasta kakao cair (Beckett, 2000 dalam (Asyik dan Ansi 2020).

Proses pembuatan cokelat secara umum meliputi pasta cokelat, lemak, gula dan susu dicampur dalam pencampuran tipe bola (ball mill) atau biasa menggunakan mixer sampai membentuk adonan (Perangin-angin, 2017). Untuk mendapatkan penampilan mengkilap dan homogen, adonan cokelat tersebut perlu ditambah sedikit lesitin. Alat ini juga berfungsi sebagai menghalus awal untuk mengecilkan ukuran partikel adonan yang semula 300 mikron menjadi 100 mikron. Waktu yang diperlukan untuk penghalusan adonan cokelat adalah kurang lebih $12-15$ jam. Pada suhu $50-55^{\circ} \mathrm{C}$. Perbandingan total berat adonan dengan berat bola penghalus adalah 1:2.

Proses conching dilakukan untuk menguapkan sisa air dan senyawa penyebab cacat citarasa (off-flavor) seperti citarasa asam dari dalam adonan cokelat Talbot (2009). Suhu conching diatur antara $50-55^{\circ} \mathrm{C}$ selama 3 jam secara terus-menerus. Pada saat conching, ditambahkan soda kue, lesitin, dan vanilli. Adonan cokelat siap cetak melewati proses kondisioning agar diperoleh hasil cetakan yang sempurna. Cokelat yang telah keluar dari mesin concing yaitu berupa adonan cokelat yang masih bersuhu sekitar $48^{\circ} \mathrm{C}$. Pada tahap ini seluruh kristal lemak di dalam adonan masih mencair. Setelah itu adonan dilakukan proses tempering hingga suhu adonan turun secara perlahan menjadi $33^{\circ} \mathrm{C}$ untuk pembentukan kristal lemak yang teratur. Sambil dituang ke dalam cetakan, suhu adonan akan terus turun sampai $26^{\circ} \mathrm{C}$. Di dalam cetakan suhu adonan akan meningkat kembali mendekati suhu kamar.

\section{CONCHING}

Conching merupakan dua fase yang terdiri dari dua tahap. Tahap pertama proses conching bertujuan untuk dapat mengurangi tingkat kelembaban pada cokelat, dimana beberapa senyawa volatile yang terdapat pada cokelat dari hasil fermentasi kakao dihilangkan dan dipercepat proses bersatunya lemak cokelat dengan bahan utama dalam pembuatan cokelat yaitu pasta kakao (Di Mattia, et al. 2014). Pada tahap kedua yang bertujuan untuk menghomogenkan semua bahan dalam pembuatan cokelat seperti pasta kakao, lemak cokelat, lesitin, serta gula menjadi suatu padatan.

Lama conching yang dilakukan sangat dipengaruhi oleh suhu conching yang digunakan serta kecepatan proses pencampuran karena proses utama yang paling penting pada proses conching adalah pada proses pencampuran yang dialiri oleh panas (Bolenz,et al., 2014). Pencampuran conching yang dilakukan pada suhu tinggi bertujuan untuk menghasilkan partikel yang sangat kecil pada lemak kakao pada pembuatan cokelat. Proses cocnhing yang dilakukan pada pembuatan cokelat yang dilakukan pada suhu dibawah $50^{\circ} \mathrm{C}$ lebih disarankan karena untuk menghindari terjadinya reasksi maillard. Conching memainkan peran penting dalam pembentukan rasa pada cokelat karena penghilangan senyawa volatil yang tidak diinginkan, kadar air pada cokelat, dan yang paling utama adalah menurunkan partikel pada adonan cokelat (Engeseth, 2018). Menurut Wolf (2017), lama conching berpengaruh terhadap viskositas dari produk cokelat, suhu conching yang tinggi serta penggunaan bahan seperti susu atau gula pad pembuatan cokelat akan menghasilkan viskositas cokelat yang diinginkan diantaranya adalah padat pada suhu ruang. Nilai viskositas masa cokelat bervariasi antara 1-4\% dengan peningkatan pada setiap kenaikan suhu conching $1^{\circ} \mathrm{C}$.

Senyawa fenolik seperti polifenol adalah senyawa yang penting pada cokelat. Senyawa tersebut memnjadi salah satu dayatarik konsumen dalam memilih produk tersebut. Kandungan senyawa fenolik dalam cokelat dipengaruhi oleh proses pengolahan cokelat serta bahan baku yang digunakan (Di Mattia et al., 2014). Beberapa penelitian telah dilakukan mengenai pengaruh proses conching salah satunya dilakukan oleh Schumacher, et al., (2009), selama proses conching terjadi penurunan kandingan polifenol di dalam cokelat, selain itu aktivitas antioksidan pada cokelat yang telah dihasilkan dari proses conching mengalami penurunan atau termasuk dalam katagori lemah. Penurunan tersebut dikarenakan oleh suhu serta lama conching yang digunakan dalam proses pembuatan cokelat. Pengaruh conching terhadap sifat fungsional pada cokelat dapat dilitah pada Tabel 1. 
Tabel 1. Pengaruh Conching Terhadap Sifat Fungsional Cokelat

\begin{tabular}{|c|c|c|c|c|c|}
\hline No & Jenis Cokelat & $\begin{array}{l}\text { Suhu dan } \\
\text { Lama } \\
\text { Conching }\end{array}$ & $\begin{array}{l}\text { Parameter } \\
\text { Utama }\end{array}$ & $\begin{array}{l}\text { Aktivitas } \\
\text { Antioksidan }\end{array}$ & Sumber \\
\hline 1 & Dark Chocolate & $\begin{array}{c}90^{\circ} \mathrm{C} \text { selama } \\
9 \mathrm{Jam} \text { dan } \\
60^{\circ} \mathrm{C} \text { selama } \\
6 \text { Jam }\end{array}$ & $\begin{array}{l}\text { Aktivitas } \\
\text { Antioksidan }\end{array}$ & $\begin{array}{l}\text { Aktivitas } \\
\text { Antioksidan } \\
\text { Kuat }\end{array}$ & (Di Mattia et al. 2014) \\
\hline 2 & $\begin{array}{l}\text { Milk Chocolate } \\
\text { Penambahan } \\
\text { Jahe Instan }\end{array}$ & $\begin{array}{c}28^{\circ} \mathrm{C} \text { selama } \\
10 \text { menit, } \\
40^{\circ} \mathrm{C} \text { selama } \\
20 \text { menit, dan } \\
30^{\circ} \mathrm{C} \text { selama } \\
10 \text { menit, }\end{array}$ & $\begin{array}{l}\text { Aktivitas } \\
\text { Antioksidan }\end{array}$ & $\begin{array}{l}\text { Aktivitas } \\
\text { Antioksidan } \\
\text { Kuat }\end{array}$ & $\begin{array}{l}\text { (Arif, Tamrin, and } \\
\text { Syukri 2017) }\end{array}$ \\
\hline 3 & Dark Chocolate & 4 Jam & $\begin{array}{l}\text { Aktivitas } \\
\text { Antioksidan }\end{array}$ & $\begin{array}{l}\text { Aktivitas } \\
\text { Antioksidan } \\
\text { kuat }\end{array}$ & (Ramlan, et al., 2018) \\
\hline 4 & Milk Chocolate & $\begin{array}{c}40^{\circ} \mathrm{C} \text { selama } \\
4 \text { Jam }\end{array}$ & $\begin{array}{l}\text { Aktivitas } \\
\text { Antioksidan }\end{array}$ & $\begin{array}{l}\text { Aktivitas } \\
\text { Antioksidan } \\
\text { Lemah }\end{array}$ & $\begin{array}{l}\text { (Suprayatmi, et al., } \\
\text { 2019) }\end{array}$ \\
\hline 5 & Cokelat Bubuk & - & $\begin{array}{l}\text { Aktivitas } \\
\text { Antioksidan }\end{array}$ & $\begin{array}{c}\text { Aktivitas } \\
\text { Antioksidan } \\
\text { Kuat }\end{array}$ & (Moreira et al. 2018) \\
\hline 7 & Dark Chocolate & - & $\begin{array}{l}\text { Aktivitas } \\
\text { Antioksidan }\end{array}$ & $\begin{array}{l}\text { Aktivitas } \\
\text { Antioksidan } \\
\text { Kuat }\end{array}$ & $\begin{array}{l}\text { (Nurhayati and Sareal } \\
\text { 2008) }\end{array}$ \\
\hline 8 & Dark Chocolate & - & $\begin{array}{l}\text { Aktivitas } \\
\text { Antioksidan }\end{array}$ & $\begin{array}{l}\text { Aktivitas } \\
\text { Antioksidan } \\
\text { Kuat }\end{array}$ & $\begin{array}{l}\text { (Urbańska and } \\
\text { Kowalska 2019) }\end{array}$ \\
\hline 9 & Dark Chocolate & - & $\begin{array}{l}\text { Aktivitas } \\
\text { Antioksidan }\end{array}$ & $\begin{array}{l}\text { Aktivitas } \\
\text { Antioksidan } \\
\text { Kuat }\end{array}$ & (Marder et al., 2012) \\
\hline 10 & Dark Chocolate & $\begin{array}{l}60^{\circ} \mathrm{C}-80^{\circ} \mathrm{C} \\
\text { selama } 12- \\
13 \text { jam }\end{array}$ & $\begin{array}{l}\text { Aktivitas } \\
\text { Antioksidan }\end{array}$ & $\begin{array}{l}\text { Aktivitas } \\
\text { Antioksidan } \\
\text { Kuat }\end{array}$ & $\begin{array}{c}\text { ( Özgüven, Berktaş, et } \\
\text { al., 2016) }\end{array}$ \\
\hline
\end{tabular}

Berdasarkan beberapa penelitian yang telah dilkaukan sebelumnya dapat dilihat bahwa proses conching pada pembuatan cokelat tidak berpengaruh terhadap menurunya sifat fungsional dari cokelat dilihat aktivitas antioksidanya. Cokelat yang dihasilkan dari proses conching memiliki aktivitas antioksidan yang termasuk kedalam katagori kuat. Sejalan dengan penelitian Di Mattia et al., (2014), Dark chocolate yang dihasilkan dari proses conching pada suhu $90^{\circ} \mathrm{C}$ selama 9 jam dan $60^{\circ} \mathrm{C}$ selama 6 jam memiliki aktivitas antioksidan yang kuat. Hal tersebut menunjukan walau polifenol pada cokelat mudah rusak pada suhu tinggi, akan tetapi proses conching pada pembuatan cokelat tidak berpengaruh terhadap menurunnya sifat fungsional pada cokelat (Tamrin dan Syukri 2017) 


\section{KESIMPULAN}

Conching merupakan salah satu proses yang paling penting dalam pembuatan cokelat dalam menyatukan adonan, memberikan cita rasa yang baik pada cokelat, serta memberikan tekstur yang baik pada cokelat. Proses conching yang digunakan pada proses pembuatan cokelat tidak berpengaruh terhadap menurunnya sifat fungsional pada cokelat dilihat dari aktivitas antioksidanya. Cokelat yang dihasilkan melalui proses conching memiliki aktivitas antioksidan yang masuk dalam kategori kuat.

\section{DAFTAR PUSTAKA}

Arif, Marhana, Tamrin, and Syukri. 2017. "Pengaruh Penambahan Karagenan Dan Jahe Terhadap Organoleptik Dan Sifat Fisikokimia Cokelat Batang." J. Sains dan Teknologi Pangan (JSTP) 2(2): 394-404.

Asriati, Dyah Wuri et al. 2018. "PENGARUH PENAMBAHAN POLIFENOL TERHADAP KARAKTERISTIK MILK CHOCOLATE COUVERTURE DAN ANALOG The Effect of Polyphenol Addition to Milk Chocolate Couverture and Analog Characteristics." : 83-96.

Asyik, Nur, and Azhar Ansi. 2020. "Proses Pengolahan Sekunder Biji Kakao Menjadi Produk Olahan Kakao Setengah Jadi." Prosiding Seminar Nasional Agribisnis: 43-47.

Bolenz, Siegfried, André Manske, and Michael Langer. 2014. "Improvement of Process Parameters and Evaluation of Milk Chocolates Made by the New Coarse Conching Process." European Food Research and Technology 238(5): 863-74.

Braga, Soraia C.G.N. et al. 2018. "Study of Volatile Profile in Cocoa Nibs, Cocoa Liquor and Chocolate on Production Process Using GC $\times$ GC-QMS." Microchemical Journal 141(2017): 353-61. https://doi.org/10.1016/j.microc.2018.05.042.

Engeseth, Nicki J., and Marlon Fernando Ac Pangan. 2018. "Current Context on Chocolate Flavor Development-a Review." Current Opinion in Food Science 21: 84-91. https://doi.org/10.1016/j.cofs.2018.07.002.

Gültekin-Özgüven, Mine, ljlal Berktaş, and Beraat Özçelik. 2016. "Influence of Processing Conditions on Procyanidin Profiles and Antioxidant Capacity of Chocolates: Optimization of Dark Chocolate Manufacturing by Response Surface Methodology." LWT - Food Science and Technology 66: 252-59.

Hasibuan, Abdul Muis, and Rita Nurmalina. 2012. "PENGARUH PENCAPAIAN KEBIJAKAN PENERAPAN BEA Eksport DANPENERIMAAN PETANI KAKAO ( Suatu Pendekatan Dinamika Sistem ) THE IMPACT OF EXPORT TAX POLICY AND COCOA ' GERNAS' PROGRAM ACHIEVEMENT TO COCOA DOWNSTREAM INDUSTRY PERFORMANCE AND FARMERS ' REVENUE ( A." Buletin RISTRI3 (Juli): 157-70.

Indriani, lin Trisni, Ansarullah, and RH.Fitri Fardilla. 2019. "J. Sains Dan Teknologi Pangan (JSTP) ISSN: 2527-6271 2017." Karakteristik Tepung Suweg (Amorphophallus paeoniifolius) Termodifikasi Heat Moisture Treatment (HMT) Pada Produk Mie Kaya Serat 4(2): 2272-84.

Marder, R., N. Medeiros, C. Funchal, and C. Dani $\square$. 2012. "Phenolic Content and Total Antioxidant Activity of Different Types of Chocolate, Milk, Dark, Half-Dark and Soy, in Cerebral Cortex of Wistar Rats." Free Radical Biology and Medicine 53: S90-91.

Di Mattia, Carla et al. 2014. "Effect of Different Conching Processes on Procyanidin Content and Antioxidant Properties of Chocolate." Food Research International 63: 367-72. http://dx.doi.org/10.1016/j.foodres.2014.04.009.

Maulana, Arif, and Fitri Kartiasih. 2017. "Analysis of Indonesian Cocoa Exports to Nine Destination Countries 2000-2014." Jurnal Ekonomi dan Pembangunan Indonesia 17(2): 103-17.

Moreira, Igor Magalhães da Veiga et al. 2018. "Volatile Compounds and Protein Profiles Analyses of Fermented Cocoa Beans and Chocolates from Different Hybrids Cultivated in Brazil." Food Research International 109(2017): 196-203. https://doi.org/10.1016/j.foodres.2018.04.012.

Nurhayati, Lany, and Tanah Sareal. 2008. "Persentase Total Aktivitas Antioksidan Dark Chocolate Dan 
Milk Chocolate Secara Spektrofotometri." : 70-80.

Perangin-angin, Mawar Indah. "UJI ORGANOLEPTIK PRODUK PERMEN COKELAT DENGAN VARIASI PENAMBAHAN VIRGIN COCONUT OIL ( VCO )."

Praseptiangga, Danar, Yasmin Nabila, and Dimas Rahadian Aji Muhammad. 2018. "Kajian Tingkat Penerimaan Panelis Pada Dark Chocolate Bar Dengan Penambahan Bubuk Kayu Manis (Cinnamomum Burmannii)." Caraka Tani: Journal of Sustainable Agriculture 33(1): 78-88.

Talbot, Geoff. 2009. Science and Technology of Enrobed and Filled Chocolate, Confectionery and Bakery Products Science and Technology of Enrobed and Filled Chocolate, Confectionery and Bakery Products.

Urbańska, Bogumiła, and Jolanta Kowalska. 2019. "Comparison of the Total Polyphenol Content and Antioxidant Activity of Chocolate Obtained from Roasted and Unroasted Cocoa Beans from Different Regions of the World." Antioxidants 8(8). 